\title{
Protection of Zr Alloy under High-Temperature Air Oxidation: A Multilayer Coating Approach
}

\author{
Dmitrii V. Sidelev*(D, Maxim S. Syrtanov, Sergey E. Ruchkin, Alexey V. Pirozhkov and Egor B. Kashkarov \\ School of Nuclear Science and Engineering, National Research Tomsk Polytechnic University, \\ 634050 Tomsk, Russia; maxim-syrtanov@mail.ru (M.S.S.); ruchkin.2010.2010@mail.ru (S.E.R.); \\ alpir11260@gmail.com (A.V.P.); egor_kashkarov@mail.ru (E.B.K.) \\ * Correspondence: sidelevdv@tpu.ru; Tel.: +7-3822-70-17-77 (ext. 2595)
}

Citation: Sidelev, D.V.; Syrtanov, M.S.; Ruchkin, S.E.; Pirozhkov, A.V.; Kashkarov, E.B. Protection of Zr Alloy under High-Temperature Air Oxidation: A Multilayer Coating Approach. Coatings 2021, 11, 227 https://doi.org/10.3390/ coatings 11020227

Academic Editor: Hideyuki Murakami

Received: 31 January 2021

Accepted: 11 February 2021

Published: 13 February 2021

Publisher's Note: MDPI stays neutral with regard to jurisdictional claims in published maps and institutional affiliations.

Copyright: (c) 2021 by the authors. Licensee MDPI, Basel, Switzerland. This article is an open access article distributed under the terms and conditions of the Creative Commons Attribution (CC BY) license (https:// creativecommons.org/licenses/by/ $4.0 /)$.

\begin{abstract}
Metallic Cr and multilayer $\mathrm{CrN} / \mathrm{Cr}$ coatings with a thickness of $2.5 \mu \mathrm{m}$ were deposited onto E110 alloy by magnetron sputtering. Oxidation tests in air were performed at $1100{ }^{\circ} \mathrm{C}$ for $10-40 \mathrm{~min}$. The gravimetric measurements showed better protective properties of multilayer $\mathrm{CrN} / \mathrm{Cr}$ coatings in comparison with metallic $\mathrm{Cr}$ coating. Multilayer coating prevented fast $\mathrm{Cr}-\mathrm{Zr}$ inter-diffusion by the formation of a $\mathrm{ZrN}$ layer beneath the coating. The appearance of $\mathrm{ZrN}$ is caused by interaction with nitrogen formed from the decomposition of $\mathrm{CrN}$ to $\mathrm{Cr}_{2} \mathrm{~N}$ phases. Optical microscopy revealed a residual $\mathrm{Cr}$ layer for the multilayer $\mathrm{CrN}(0.25 \mu \mathrm{m}) / \mathrm{Cr}(0.25 \mu \mathrm{m})$ coating for all the oxidation periods. Additional in situ X-ray diffraction (XRD) studies of coated alloy during linear heating up to $1400{ }^{\circ} \mathrm{C}$ showed that the formation of the $\mathrm{Cr}_{2} \mathrm{Zr}$ phase in the case of multilayer coatings occurred at a higher $\left(\sim 150^{\circ} \mathrm{C}\right)$ temperature compared to metallic $\mathrm{Cr}$. Multilayer coatings can decrease the nitrogen effect for $\mathrm{Zr}$ alloy oxidation. Uniform and thinner oxide layers of $\mathrm{Zr}$ alloy were observed when the multilayer coatings were applied. The highest oxidation resistance belonged to the $\mathrm{CrN} / \mathrm{Cr}$ coating with a multilayer step of $0.25 \mu \mathrm{m}$.
\end{abstract}

Keywords: high-temperature oxidation; zirconium alloys; accident tolerant fuel; multilayer coatings; chromium; chromium nitride; magnetron sputtering; in situ XRD

\section{Introduction}

Nowadays, a wide variety of materials have been studied as protective coatings on zirconium fuel claddings to improve its resistance under normal operation $\left(\sim 360^{\circ} \mathrm{C}\right.$, 18.6 $\mathrm{MPa}$ ) and design-based accident (DBA, up to $1200{ }^{\circ} \mathrm{C}$ ) conditions. The majority of scientific groups and organizations suggest metallic chromium as the most suitable material for the development of accident tolerant fuel (ATF) claddings [1-6]. Growth of a chromia $\left(\mathrm{Cr}_{2} \mathrm{O}_{3}\right)$ layer on surface of $\mathrm{Cr}$-coated $\mathrm{Zr}$ alloy decelerates oxygen diffusion to the alloy and significantly increases its oxidation resistance (e.g., by an order of magnitude at $1200{ }^{\circ} \mathrm{C}$ for $10 \mathrm{~min}$ [7]). However, $\mathrm{Cr}-\mathrm{Zr}$ inter-diffusion significantly increases at high temperatures especially for a $\beta-Z r$ phase [8-10]. Thus, during oxidation, $\mathrm{Cr}$ coatings can be also consumed by diffusion into $\mathrm{Zr}$ alloys with subsequent formation of an eutectic $\mathrm{Cr}-\mathrm{Zr}$ phase with low melting temperature $\left(\sim 1332^{\circ} \mathrm{C}\right)$. Both processes-(1) surface oxidation of the $\mathrm{Cr}$ coating and (2) $\mathrm{Cr}-\mathrm{Zr}$ inter-diffusion at the coating/alloy interface-are key factors determining the duration and temperature range of the protective scale of the $\mathrm{Cr}$-coated $\mathrm{Zr}$ alloy in high temperature conditions.

To improve the oxidation resistance of coated $\mathrm{Zr}$ alloys, especially under beyond DBA conditions, a new coating preventing $\mathrm{Cr}-\mathrm{Zr}$ inter-diffusion should be developed. The compound coatings (e.g., $\mathrm{CrN}, \mathrm{ZrSi}_{2}$, etc.) can have better oxidation resistance than metallic $\mathrm{Cr}$ and act as a diffusion barrier [11-15]. However, high hardness and strong difference in thermal expansion coefficients of such materials in comparison with Zr alloys cause coating cracking and its spallation at high-temperature oxidation or under mechanical deformations [15]. Multilayer coatings can be more resistant to coating interruption if 
they are composed of alternating brittle and elastic layers [16,17]. Therefore, multilayers consisting of compound and metallic layers can be used as the barrier layer to prevent the $\mathrm{Cr}-\mathrm{Zr}$ inter-diffusion, while a chromium coating deposited on top of the multilayers can act as the main protective layer that prevents inward diffusion of oxygen to $\mathrm{Zr}$ alloy similar to single layer metallic $\mathrm{Cr}$ coatings.

Several compound coatings ( $\mathrm{Ti}_{2} \mathrm{AlC}, \mathrm{Cr}_{2} \mathrm{AlC}, \mathrm{CrAlN}, \mathrm{CrAlSiN}, \mathrm{TiN}, \mathrm{CrN}$, etc.) were already studied in normal operation and accident conditions [14,18-22]. The last results show that the chromium nitride coating has a good corrosion and oxidation resistance in both conditions. Moreover, the thermal expansion coefficient of $\mathrm{CrN}\left((3.2-5.4) \times 10^{-6}{ }^{\circ} \mathrm{C}^{-1}\right)$ is close to that for $\mathrm{Zr}$ alloys $\left((5.7-9.3) \times 10^{-6}{ }^{\circ} \mathrm{C}^{-1}\right)$. Thus, the coating consisting of $\mathrm{CrN} / \mathrm{Cr}$ multilayers and outer $\mathrm{Cr}$ film can be promising to protect $\mathrm{Zr}$ claddings.

This article focuses on investigation of the oxidation behavior of the E110 alloy with multilayer $\mathrm{CrN} / \mathrm{Cr}$ coatings in air. The metallic $\mathrm{Cr}$ and multilayer $\mathrm{CrN} / \mathrm{Cr}$ coatings were deposited by magnetron sputtering. Oxidation tests were performed in air at $1100{ }^{\circ} \mathrm{C}$ for $10-40 \mathrm{~min}$. Finally, oxidation behavior of the coatings was discussed based on the analysis of the samples after oxidation, and additionally in situ XRD studies at high-temperature heating up to $1400{ }^{\circ} \mathrm{C}$ were performed.

\section{Experimental Details}

\subsection{Coating Deposition}

The coatings were deposited on E110 alloy samples using the ion-plasma installation equipped with the multi-cathode magnetron sputtering systems and planetary substrateholder. More details about the deposition system are presented in [23].

The E110 alloy $\left(15 \times 15 \times 2 \mathrm{~mm}^{3}\right)$ and polished Si (110) were used as substrates. Special holes with $\varnothing 2 \mathrm{~mm}$ were drilled in the samples to hold them during oxidation tests. The substrates were grinded and polished by SiC sandpapers (P600 $\rightarrow$ P2500), washed with technical soap $\rightarrow$ distilled water $\rightarrow 98 \%$ alcohol and dried by compressed air. Prior to coating deposition, the substrates were etched by $\mathrm{Ar}^{+}$ions at the following parameters: voltage of $2.5 \mathrm{kV}$, ion current of $45 \mathrm{~mA}$, and Ar pressure of $0.15 \mathrm{~Pa}$.

Four series of the coatings were prepared in the present study. The parameters of the coatings and their deposition conditions are shown in Table 1.

Table 1. Deposition parameters of the coatings.

\begin{tabular}{|c|c|c|c|c|c|c|c|}
\hline \multirow{2}{*}{ \# } & \multicolumn{2}{|c|}{ Multilayers } & \multirow{2}{*}{$\begin{array}{c}\text { Outer Cr Layer } \\
h_{\mathrm{Cr}}, \mu \mathrm{m}\end{array}$} & \multirow{2}{*}{$t, \min$} & \multirow{2}{*}{$U_{b}, \mathrm{~V}$} & \multirow{2}{*}{$j_{s u b}, \mathrm{~mA} / \mathrm{cm}^{2}$} & \multirow{2}{*}{$T_{s u b}, \mathrm{~K}$} \\
\hline & $N$ & $h, \mathrm{~nm}$ & & & & & \\
\hline $\mathrm{Cr}$ & - & - & 2.5 & 35 & \multirow{4}{*}{-50} & 67 & 582 \\
\hline $\mathrm{CrN} / \mathrm{Cr}-50$ & 40 & 50 & 0.5 & \multirow{3}{*}{50} & & 72 & 576 \\
\hline $\mathrm{CrN} / \mathrm{Cr}-250$ & 8 & 250 & 0.5 & & & 72 & 578 \\
\hline $\mathrm{CrN} / \mathrm{Cr}-500$ & 4 & 500 & 0.5 & & & 73 & 583 \\
\hline
\end{tabular}

Note: $N$-number of multilayers; $h$-thickness; $t$-deposition time; $U_{b}$-substrate bias; $j_{s u b}$-averaged ion current density on the substrate; $T_{\text {sub }}$-substrate temperature. The total thickness of all coatings was equal to $2.45 \pm 0.15 \mu \mathrm{m}$. The first coating type had a monolayer structure of metallic $\mathrm{Cr}$. Other coatings had a multilayer structure with alternating $\mathrm{CrN}$ and $\mathrm{Cr}$ layers, where the first layer was $\mathrm{CrN}$. Additionally, $0.5 \mu \mathrm{m}$-thick $\mathrm{Cr}$ was deposited as an outer layer.

The total operation pressure was $0.3 \mathrm{~Pa}$. The target power density of the magnetron sputtering system for deposition of $\mathrm{Cr}$ and $\mathrm{CrN}$ layers was equal to $31.5 \mathrm{~W} / \mathrm{cm}^{2}$. The infrared pyrometer Optris CTlaser 3MH1CF4 (Berlin, Germany) was used to measure the substrate temperature during coating deposition. The E110 samples were fixed in a stainless-steel holder; a small area $\left(\sim 5-10 \mathrm{~mm}^{2}\right)$ remained uncoated.

\subsection{Oxidation Tests}

High-temperature oxidation of the samples was performed using an atmospheric furnace (ATS 3210, Applied Test Systems Inc., Butler, PA, USA). All tests were started from $500^{\circ} \mathrm{C}$, followed by a temperature ramp up to $1100^{\circ} \mathrm{C}$ with a heating rate of $\sim 20-25^{\circ} \mathrm{C} / \mathrm{min}$. Next, 
the samples were isothermally oxidized at $1100{ }^{\circ} \mathrm{C}$ for $10,20,30$ and $40 \mathrm{~min}$. After oxidation, the furnace was opened, and the samples were naturally cooled to room temperature. The temperature profiles are shown in Figure 1.

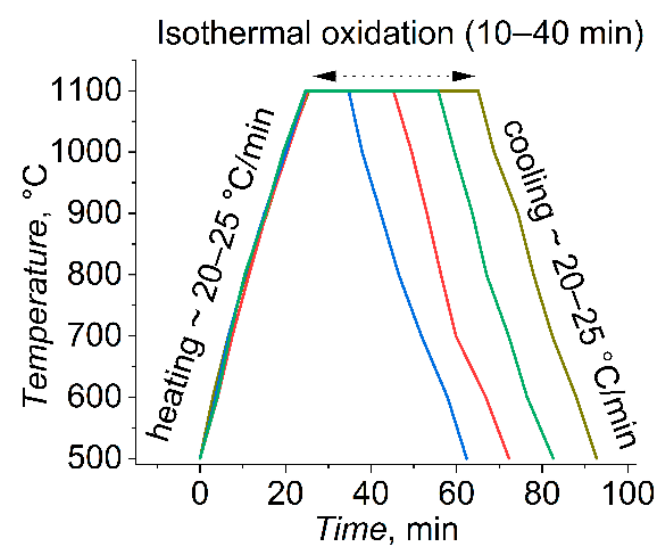

Figure 1. Temperature profiles during oxidation tests.

\subsection{Sample Characterization}

The thickness and microstructure of the as-deposited coatings were analyzed by scanning electron microscopy (SEM) using Quanta 200 3D (FEI, Hillsboro, OR, USA). The weight gain of the samples was measured using an analytical balance machine CP124 $\mathrm{S}$ (Sartorius, Goettingen, Germany) with an accuracy of $10^{-4} \mathrm{~g}$. The weight gain was calculated only for coated area, so the next expression was used [6]:

$$
W_{C r}=\frac{\Delta m_{C r}}{S_{C r}}
$$

where $S_{C r}$-the area of coated part of the sample (in $\left.\mathrm{cm}^{2}\right) ; \Delta m_{\mathrm{Cr}}$-the weight gain of the coated part of the sample (in $\mathrm{mg}$ ).

Cross-sections of the samples after oxidation were analyzed by optical microscopy (OM) using AXIOVERT 200MAT (Zeiss, Jena, Germany). The elemental distributions of the samples on depth were investigated by a glow discharge optical emission spectroscopy (GDOES) using GD-Profiler 2 (HORIBA Scientific, Kyoto, Japan). Phase composition of the samples was studied by X-Ray diffraction XRD-7000S (Shimadzu, Kyoto, Japan) in a BraggBrentano configuration using $\mathrm{CuK} \alpha$ radiation at $40 \mathrm{kV}$ and $30 \mathrm{~mA}$. The interpretation of the diffraction patterns and identification of reflections were carried out using PDF-4+ (ICDD, Newtown Township, PA, USA) software. The weight fractions of the crystalline phases were calculated by the reference intensity ratio using the formula [24]:

$$
W_{k}=\frac{I_{k}^{\max } / R I R_{k}}{\sum_{i}^{I_{i}^{\max }} / R_{1}}
$$

where $W_{k}$-weight fraction of an analyzed phase; $I_{k}^{\max }$-maximum intensity value of an analyzed phase; $R I R_{k}$ - reference intensity ratio of an analyzed phase.

In situ XRD was performed by synchrotron radiation source VEPP-3 (electron storage) at the station "Precision diffractometry II" in Siberian Synchrotron and Terahertz Radiation Center of the Budker Institute of Nuclear Physics of the Siberian Branch of Russian Academy of Science. Phase transitions were investigated using a high temperature chamber HTK 2000N (Anton Paar, Graz, Austria) in vacuum. The experimental parameters were as follows: wavelength $-1.0102 \AA$; temperature range $-25-1400^{\circ} \mathrm{C}$; heating rate $-50^{\circ} \mathrm{C} / \mathrm{min}$; residual pressure- $10^{-3} \mathrm{~Pa}$. 


\section{Results}

\subsection{The As-Deposited Coatings}

Figure 2 shows cross-sections of the as-deposited coatings on Si substrates.
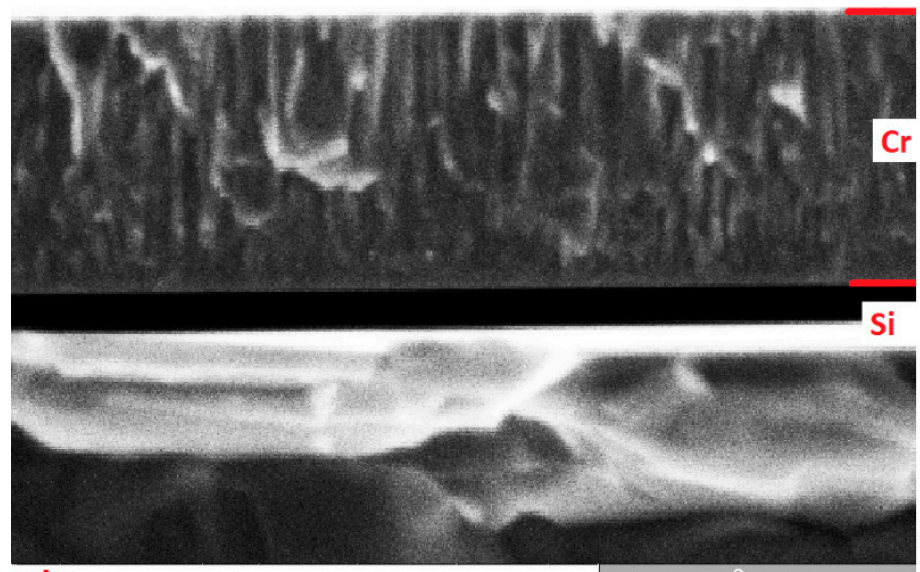

a)
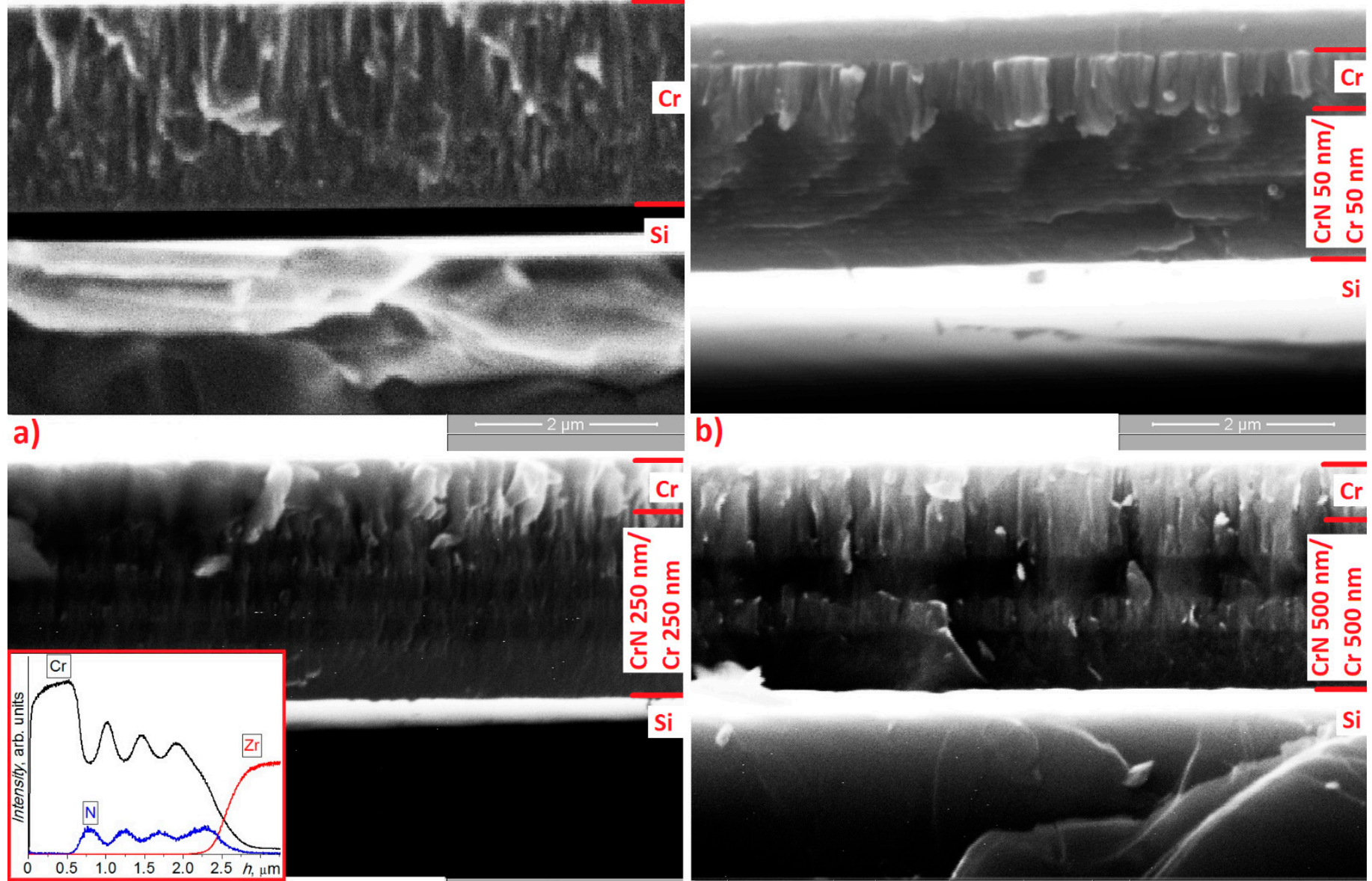

c)

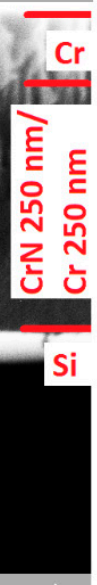

\section{b) \\ )}
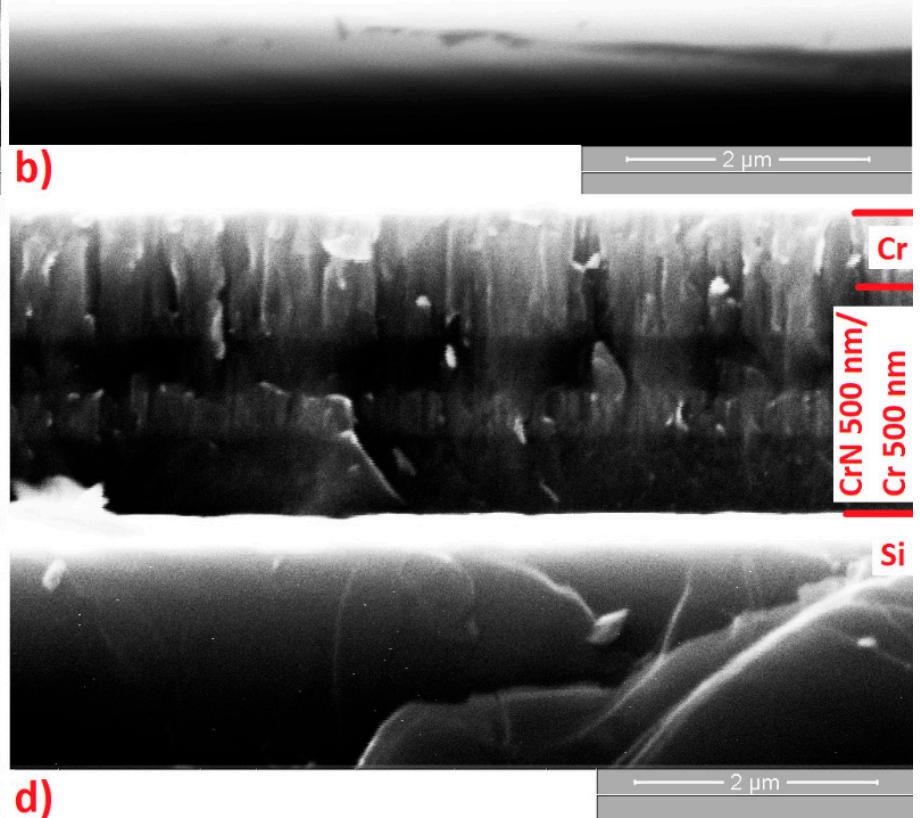

Figure 2. The cross-section SEM images of the as-deposited coatings on Si substrate: (a) $\mathrm{Cr}$ coating; (b) $\mathrm{CrN} / \mathrm{Cr}-50$ coating; (c) $\mathrm{CrN} / \mathrm{Cr}-250$ coating; (d) $\mathrm{CrN} / \mathrm{Cr}-500$ coating. Elemental depth distribution in the $\mathrm{CrN} / \mathrm{Cr}-250$ sample is shown.

All samples have a total thickness of $\sim 2.5 \mu \mathrm{m}$. The microstructure of the coatings is dense and columnar. The $\mathrm{Cr}$ sample is a monolayer coating, while other coatings have a multilayer structure of $\mathrm{CrN}$ and $\mathrm{Cr}$. Additionally, an elemental depth distribution in the CrN/Cr-250 sample (deposited on E110 alloy) was studied using GDOES (Figure 2). an outer $\mathrm{Cr}$ layer $(\sim 0.5 \mu \mathrm{m})$ and 8 alternating $\mathrm{CrN}$ and $\mathrm{Cr}$ layers are shown with a thickness of $\sim 0.25 \mu \mathrm{m}$ (four maximums and four minimums of $\mathrm{N}$ and $\mathrm{Cr}$ signals). The transition from the coating to $\mathrm{Zr}$ alloy is uniform and smooth without any peaks or fluctuations. According to the SEM images, the CrN/Cr-50 and CrN/Cr-500 samples have a multilayer step of $\sim 0.05$ and $0.5 \mu \mathrm{m}$, respectively.

\subsection{Weight-Gain Measurements}

To analyze macro structural changes, all samples (with/without coatings) are necessarily photographed before and after oxidation tests. Their outer view is shown in Table 2. 
Table 2. The samples before and after oxidation.

\begin{tabular}{ccccc}
\hline $\begin{array}{c}\text { Uncoated E110 } \\
\text { Alloy }\end{array}$ & Cr & CrN/Cr-50 & CrN/Cr-250 & CrN/Cr-500 \\
\cline { 2 - 5 } & & & Before Oxidation & \\
\hline 6 & & & & \\
\hline
\end{tabular}
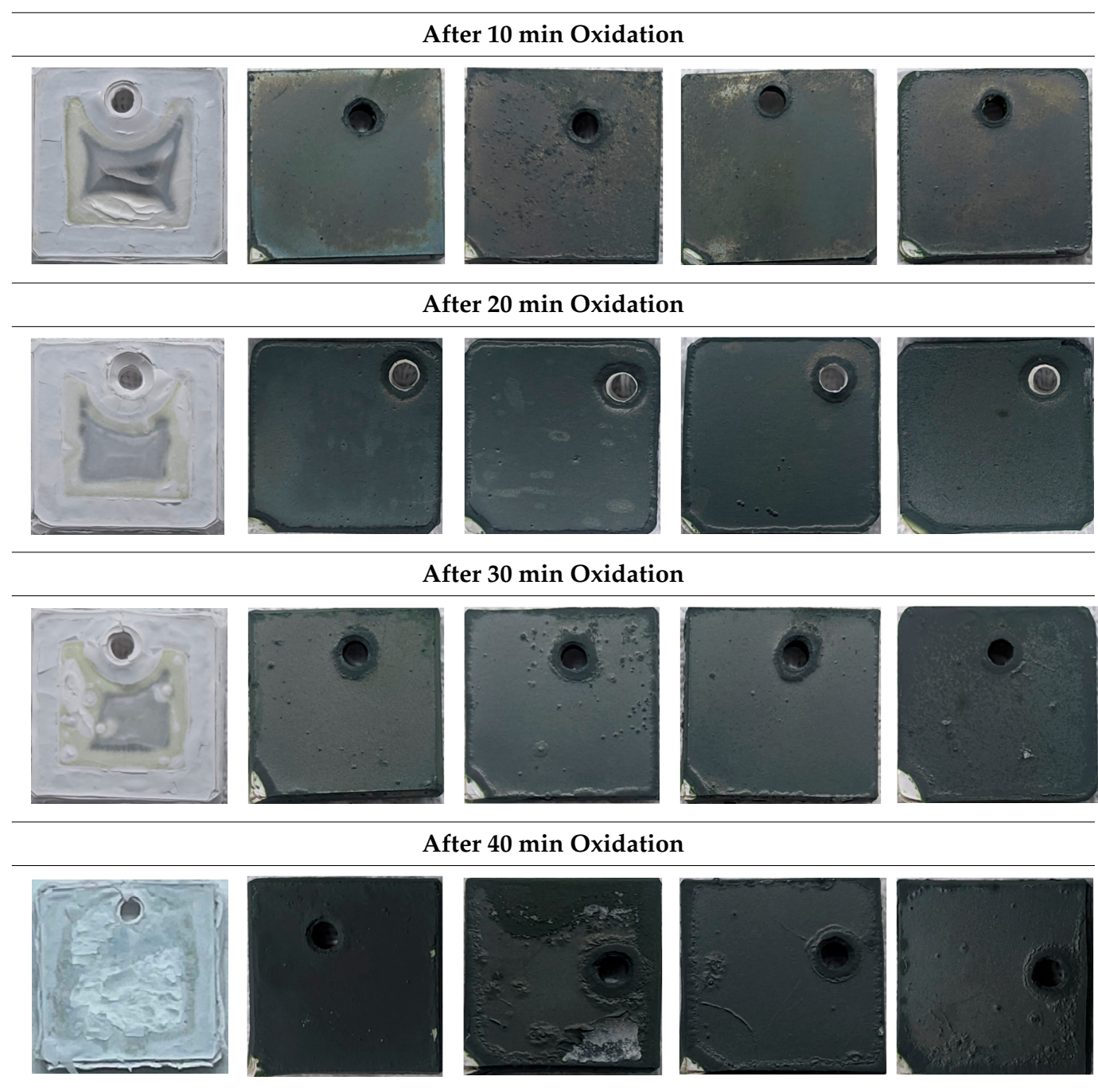

The samples have changed color after oxidation tests. The most pronounced effect is observed for the uncoated E110 alloy. This sample has a white surface, which indicated $\mathrm{ZrO}_{2}$ formation. Further spallation of $\mathrm{ZrO}_{2}$ films is found as oxidation time increases. All coated samples have a dark-green/blue-grey color corresponding to chromia. At the same time, these samples also have an uncoated area due to their fixation in the holder during coating deposition. Visual control of the $\mathrm{CrN} / \mathrm{Cr}-50$ sample shows swelling even after 10 min oxidation in air. The white-colored area in the right corner of this sample indicates coating spallation after 40 min oxidation test. Other samples also have swelling areas, but the coatings are still adherent to the alloy for all oxidation periods.

Figure 3 shows the weight gain of the samples depending on oxidation time. 


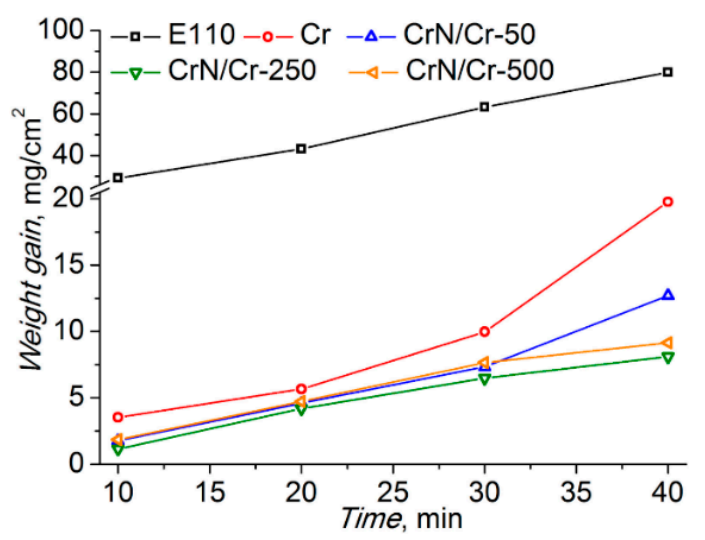

Figure 3. The weight gain of the uncoated and coated E110 alloy samples after air oxidation.

The uncoated E110 alloy has the highest weight gain, which is equal to $\sim 24 \mathrm{mg} / \mathrm{cm}^{2}$ (10 $\mathrm{min}$ ) and increases up to $\sim 80 \mathrm{mg} / \mathrm{cm}^{2}$ (40 min). The coated samples have significantly lower weight gain, but the coating type affects the oxidation kinetics. Among them, the $\mathrm{Cr}$ sample has the highest weight gain in each oxidation test, which strong rises to $\sim 10-20 \mathrm{mg} / \mathrm{cm}^{2}$ for $30-40 \mathrm{~min}$ oxidation. The samples with multilayer coatings have a comparable weight gains up to $30 \mathrm{~min}$ oxidation. Only for the CrN/Cr-50 sample was an accelerated oxidation observed after $30 \mathrm{~min}$ oxidation. The lowest weight gain belongs to the $\mathrm{CrN} / \mathrm{Cr}$-250 sample (1-9 $\mathrm{mg} / \mathrm{cm}^{2}$ depending on oxidation time).

\subsection{The Samples after Oxidation in Air}

\subsubsection{Optical Microscopy}

Two resolutions were used to observe the whole cross-section microstructure of the samples and their surface oxidation. Figure 4 shows OM images of cross-section microstructures of the samples after 40 min oxidation in air.

The microstructure of the $\mathrm{Cr}$ sample is represented by the highest depth of incursions of $\mathrm{ZrO}_{2}$ and $\mathrm{ZrN}$ in the alloy and their quantity, while an uneven layer of oxygen/nitrogenstabilized $\alpha-\operatorname{Zr}(\mathrm{O}) / \alpha-\operatorname{Zr}(\mathrm{N})$ have a thickness of $\sim 150-350 \mu \mathrm{m}$. The magnified OM image shows a $\sim 30-45 \mu$ m-thick $\mathrm{ZrO}_{2}+\mathrm{ZrN}$ layer beneath the $\mathrm{C}_{\mathrm{r} 2} \mathrm{O}_{3}$ oxide layer.

The samples with the multilayer coatings have more uniform oxide layers at their surfaces with less quantity of cracks. In general, the thickness of the $\mathrm{ZrO}_{2}+\mathrm{ZrN}$ layer is equal to $\sim 2-10 \mu \mathrm{m}$ depending on the coating type. However, the $\mathrm{CrN} / \mathrm{Cr}-50$ sample has an inhomogeneous area with a thicker oxide layer (up to $100 \mu \mathrm{m}$ ), which is highlighted by red arrows in Figure 4. In other parts of this sample, the thickness of $\mathrm{ZrO}_{2}+\mathrm{ZrN}$ layer is less than $10 \mu \mathrm{m}$. The significant difference has the $\mathrm{CrN} / \mathrm{Cr}-250$ sample, where a residual $\mathrm{Cr}$ layer is still observed in the cross-section, while other coatings have only $\mathrm{Cr}_{2} \mathrm{O}_{3}$ oxide layers (fully consumed).

The optical images of cross-section microstructures after 40 min oxidation, outer view of the samples and their weight gains indicate less oxidation of the $\mathrm{CrN} / \mathrm{Cr}-250$ sample. Thus, the comparative study on the $\mathrm{Cr}$ and $\mathrm{CrN} / \mathrm{Cr}-250$ samples is further presented. Their cross-section microstructures after 20 min oxidation are shown in Figure 5.

Despite a small difference in weight gains after 20 min oxidation, the microstructures of the $\mathrm{Cr}$ and $\mathrm{CrN} / \mathrm{Cr}-250$ samples near the surface are different. The $\mathrm{Cr}$ sample has a less uniform, thinner and discontinuous layer of residual chromium, while the continuous $\mathrm{Cr}$ layer $(\sim 1 \mu \mathrm{m})$ is found for the $\mathrm{CrN} / \mathrm{Cr}-250$ sample. 


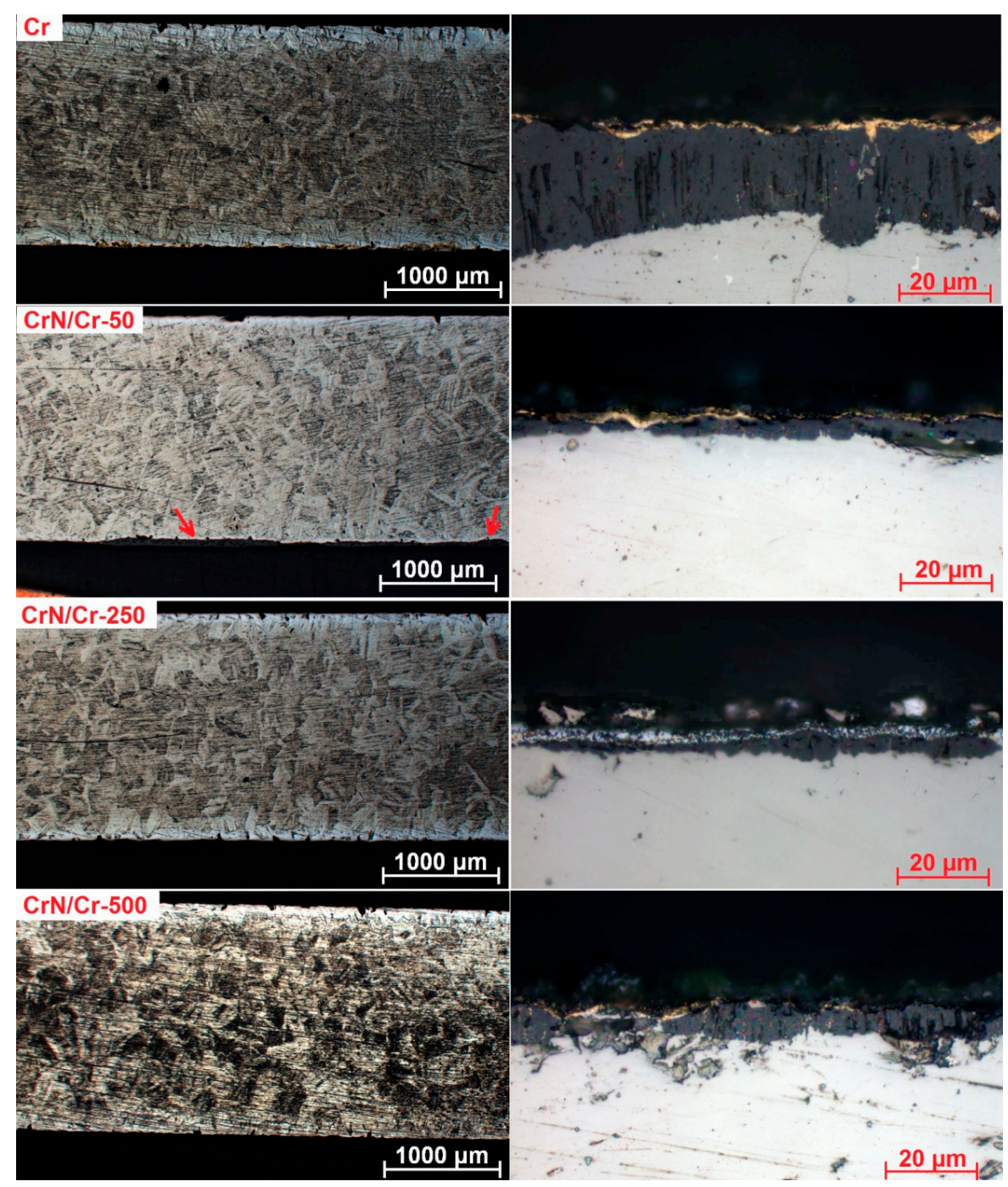

Figure 4. The optical images of the samples after 40 min oxidation.

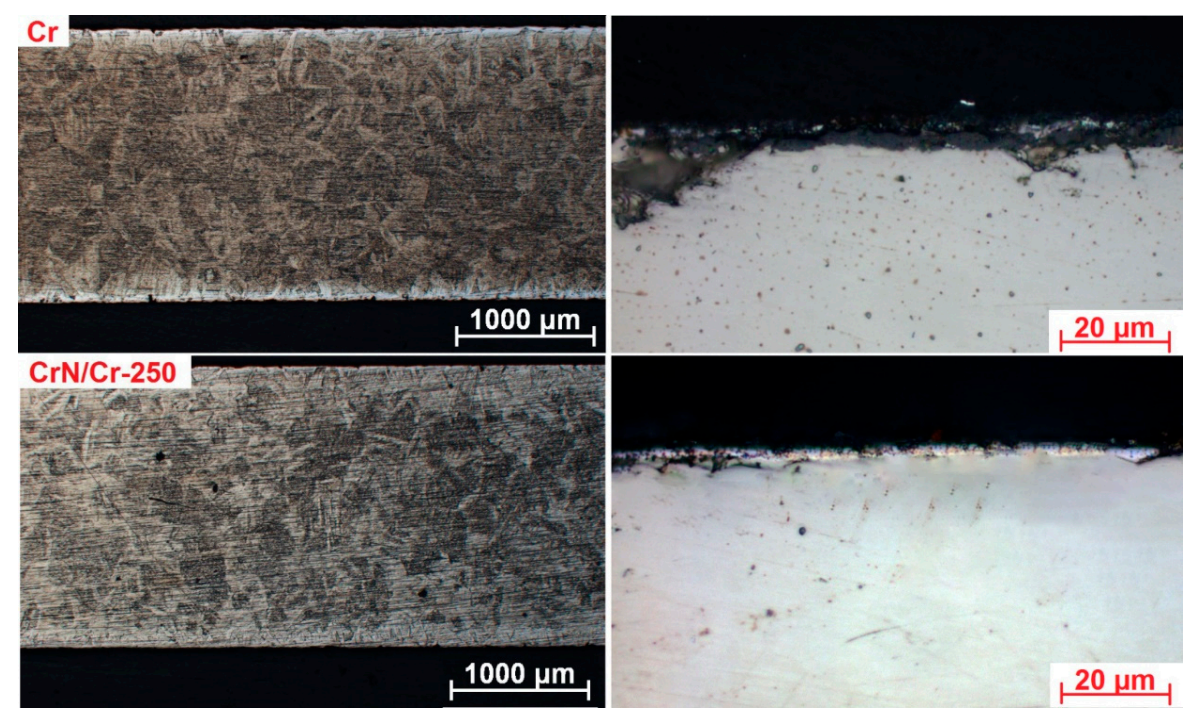

Figure 5. The cross-section microstructures of the $\mathrm{Cr}$ and $\mathrm{CrN} / \mathrm{Cr}-250$ samples after 20 min oxidation. 


\subsubsection{Elemental Distributions over a Depth}

Figure 6 shows the elemental distributions over a depth of the $\mathrm{Cr}$ and $\mathrm{CrN} / \mathrm{Cr}-250$ samples after 20,30, and 40 min oxidation tests.
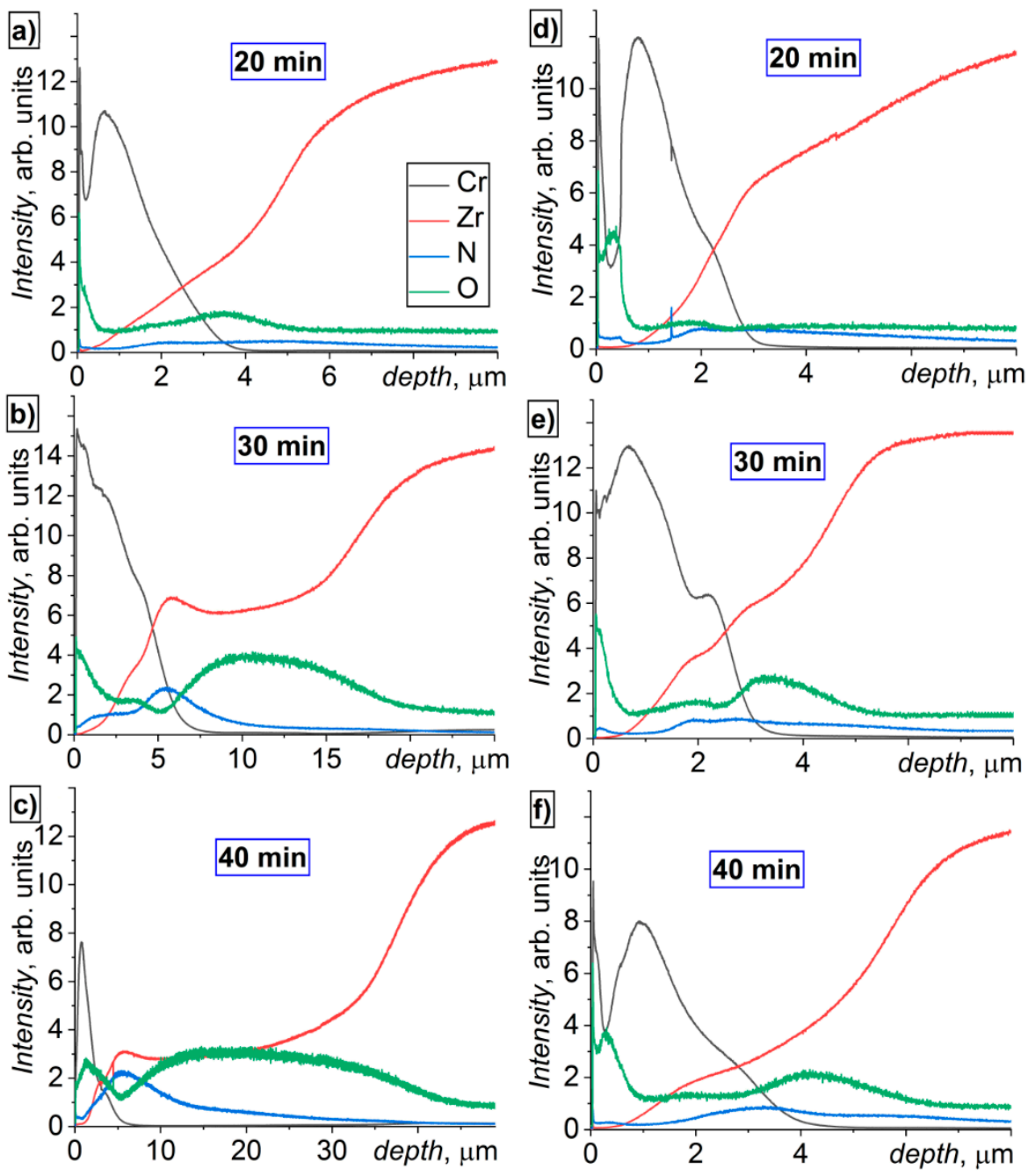

Figure 6. Depth distribution of elements in the $\mathrm{Cr}(\mathbf{a}-\mathbf{c})$ and $\mathrm{CrN} / \mathrm{Cr}-250$ (d-f) samples after 20, 30, and 40 min oxidation in air.

For the $\mathrm{Cr}$ sample (Figure 6a-c), the significant changes of elemental distributions are observed as oxidation time increases. Such behavior corresponds to transition from protective to non-protective scale of the coating [1,7], when the oxidation kinetics accelerates and the $\mathrm{ZrO}_{2}$ layer can be formed beneath the residual $\mathrm{Cr}$ layer. It is clearly seen by the change of the oxygen penetration depth from $\sim 5$ to $40 \mu \mathrm{m}$ with increasing oxidation time from 20 to $40 \mathrm{~min}$, respectively. Similar depth distributions of elements have been observed for E110 alloy with thin Cr coatings in the previous study [6].

The elemental distributions of the $\mathrm{CrN} / \mathrm{Cr}-250$ sample are less changed with oxidation time (Figure $6 \mathrm{~d}-\mathrm{f}$ ). The depth of $\mathrm{Cr}$ slowly increases from $\sim 3$ to $4 \mu \mathrm{m}$ as oxidation time changes from 20 to $40 \mathrm{~min}$. According to Figure 6f, the oxygen distribution profile indicates the formation of $\sim 2 \mu \mathrm{m}$-thick $\mathrm{ZrO}_{2}$ layer beneath the residual $\mathrm{Cr}$, which is significantly lower compared to the $\mathrm{Cr}$ sample $\left(\sim 35 \mu \mathrm{m}\right.$-thick $\left.\mathrm{ZrO}_{2}\right)$.

\subsubsection{Phase Composition}

Figure 7 shows diffraction patterns and phase content of E110 alloy with the Cr coating after air oxidation at $1100{ }^{\circ} \mathrm{C}$ for $10-40 \mathrm{~min}$. The as-deposited sample (before oxidation) is 
composed by hexagonal close package (hcp) $\alpha-\mathrm{Zr}$ (substrate) and body-centered cubic (bcc) $\alpha-\mathrm{Cr}$ (coating) phases. The phase composition of the samples significantly changes after oxidation. The content of $\alpha-\mathrm{Cr}$ decreases while $\mathrm{Zr}_{3} \mathrm{O}, \mathrm{Cr}_{2} \mathrm{O}_{3}$, monoclinic $\mathrm{m}-\mathrm{ZrO}_{2}$, and $\mathrm{ZrN}$ phases are formed after oxidation for $10 \mathrm{~min}$. The $\mathrm{Cr}_{2} \mathrm{~N}$ and tetragonal $\mathrm{t}-\mathrm{ZrO}_{2}$ phases are found at higher oxidation time (after $30 \mathrm{~min}$ ). The growth of $\mathrm{CrN}$ phase is observed after 40 min oxidation that can be caused by interacting of $\mathrm{Cr}$ with nitrogen from re-oxidation reaction [6]. The content of $\mathrm{m}-\mathrm{ZrO}_{2}$ and $\mathrm{t}-\mathrm{ZrO}{ }_{2}$ phases is increased with the oxidation time. It should be noted that no $\alpha$-Cr phase is found after 40 min oxidation, indicating full consumption of residual $\mathrm{Cr}$.
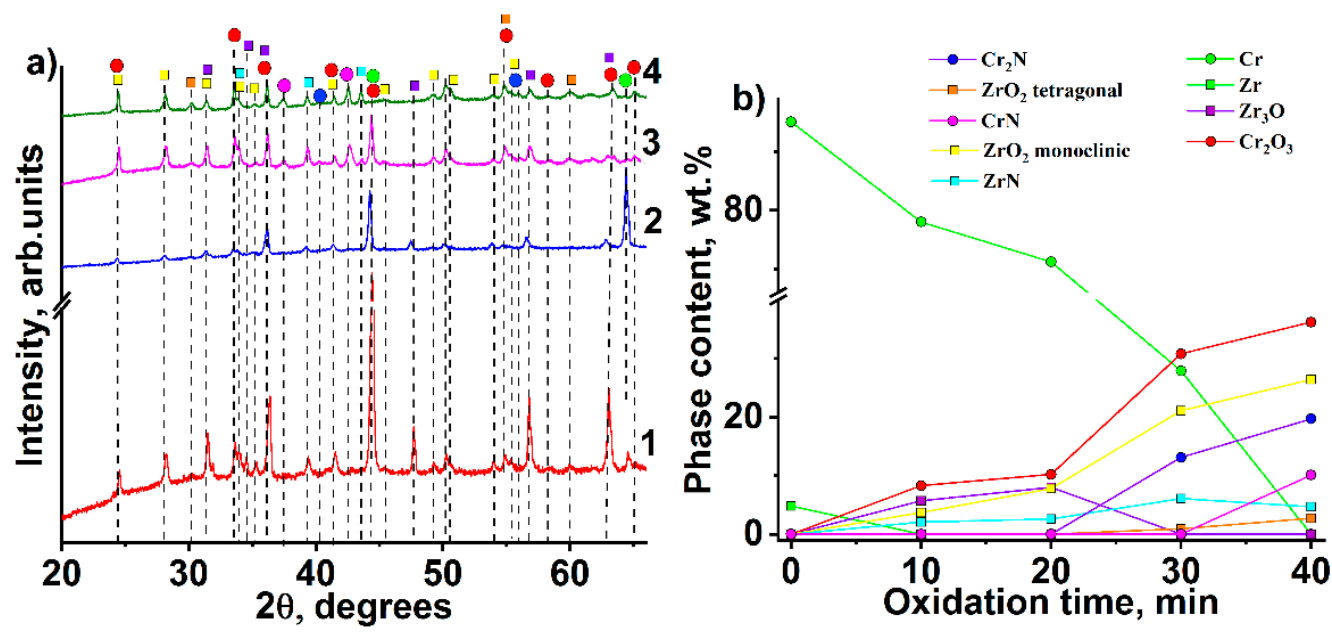

Figure 7. Diffraction patterns of the E110 alloy with the $\mathrm{Cr}$ coating after air oxidation at $1100{ }^{\circ} \mathrm{C}(\mathbf{a})$ and phase content (b) depending on oxidation time: 1-10 $\mathrm{min}, 2-20 \mathrm{~min}, 3-30 \mathrm{~min}, 4-40 \mathrm{~min}$.

In the case of the $\mathrm{CrN} / \mathrm{Cr}-250$ sample, the $\mathrm{Cr}_{2} \mathrm{~N}$ phase forms after 10 min oxidation as a result of $\mathrm{CrN}$ decomposition in the as-received coating (Figure 8). However, the $\mathrm{Cr}_{2} \mathrm{~N}$ phase disappears after oxidation during $20 \mathrm{~min}$. When the oxidation time increases up to $30 \mathrm{~min}$, the formation of the $\mathrm{t}-\mathrm{ZrO}_{2}$ phase is observed. The increase in oxidation time is accompanied by the decrease in $\mathrm{Zr}_{3} \mathrm{O}$ and the growth of the monoclinic $\mathrm{ZrO}_{2}$ phase. An important feature of the multilayer $\mathrm{CrN} / \mathrm{Cr}$ - 250 sample is the presence of a high content of residual $\alpha$-Cr (52.8 wt. \%) even after 40 min oxidation.
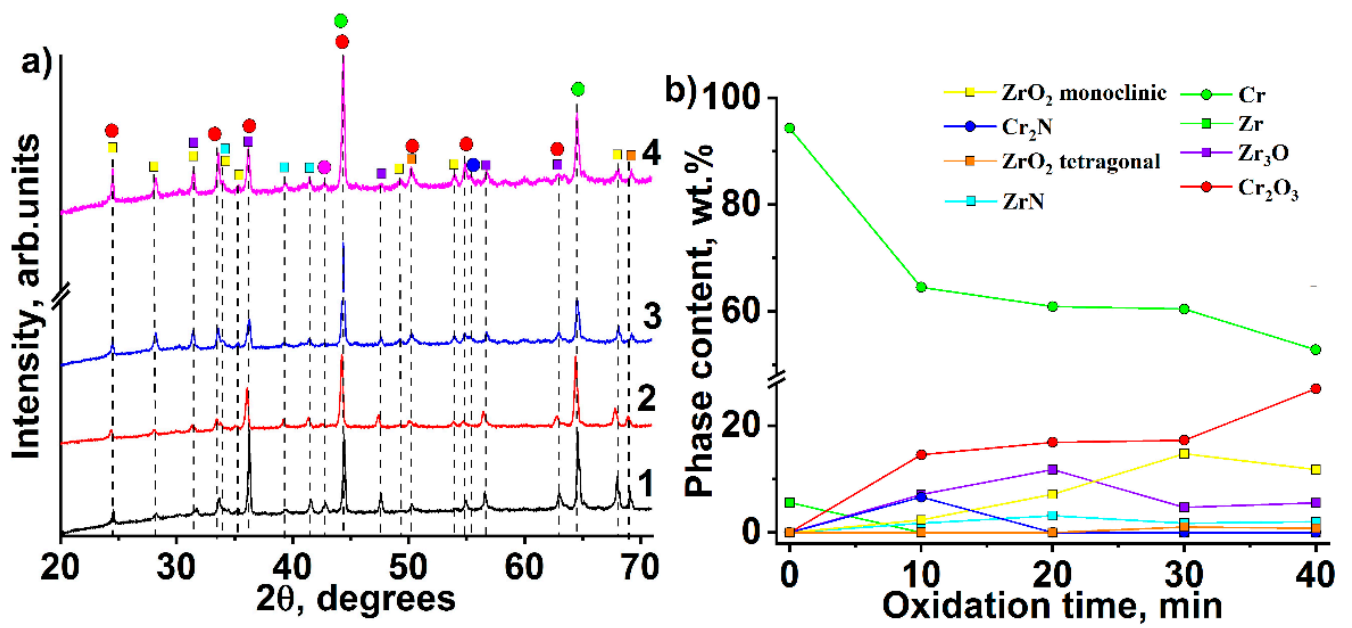

Figure 8. Diffraction patterns of the E110 alloy with the $\mathrm{CrN} / \mathrm{Cr}-250$ coating after air oxidation at $1100{ }^{\circ} \mathrm{C}$ (a) and phase content (b) depending on oxidation time: 1-10 $\mathrm{min}, 2-20 \mathrm{~min}, 3-30 \mathrm{~min}, 4-40 \mathrm{~min}$. 


\subsubsection{In Situ XRD}

In situ XRD measurements were performed on E110 alloy with the metallic $\mathrm{Cr}$ and multilayer $\mathrm{CrN} / \mathrm{Cr}-250$ coatings during linear heating in vacuum from room temperature to $1400{ }^{\circ} \mathrm{C}$ (Figures 9 and 10). The results show the effect of the multilayer approach on the diffusion barrier properties and phase formation during HT treatment of the coated E110 alloy. It can be seen that the phase composition of the $\mathrm{Cr}$ coating does not change up to $900{ }^{\circ} \mathrm{C}$ (Figure 9a). In this range, the reflections of the $\alpha-\mathrm{Zr}$ and $\alpha-\mathrm{Cr}$ phases shift toward smaller angles, indicating an increase in crystal lattice parameters due to thermal expansion. An increase in temperature results in $\alpha \rightarrow \beta$ phase transition of $\mathrm{Zr}$ at $900{ }^{\circ} \mathrm{C}$ that is consistent with $\mathrm{Zr}$ phase diagram. The intermetallic $\mathrm{Cr}_{2} \mathrm{Zr}$ phase appears when the temperature reaches $1200{ }^{\circ} \mathrm{C}$. The formation of this phase is caused by fast $\mathrm{Cr}-\mathrm{Zr}$ inter-diffusion under high temperature [25]. Meanwhile, the small amount of $\mathrm{Cr}_{2} \mathrm{O}_{3}$ phase is observed, which is related to the oxidation of surface layer of the coating. The temperature ramp from 1200 to $1400{ }^{\circ} \mathrm{C}$ is accompanied by an increase in the intensity of the $\mathrm{Cr}_{2} \mathrm{Zr}$ phase indicating growth of the $\mathrm{Cr}_{2} \mathrm{Zr}$ layer (Figure $9 \mathrm{~b}$ ).
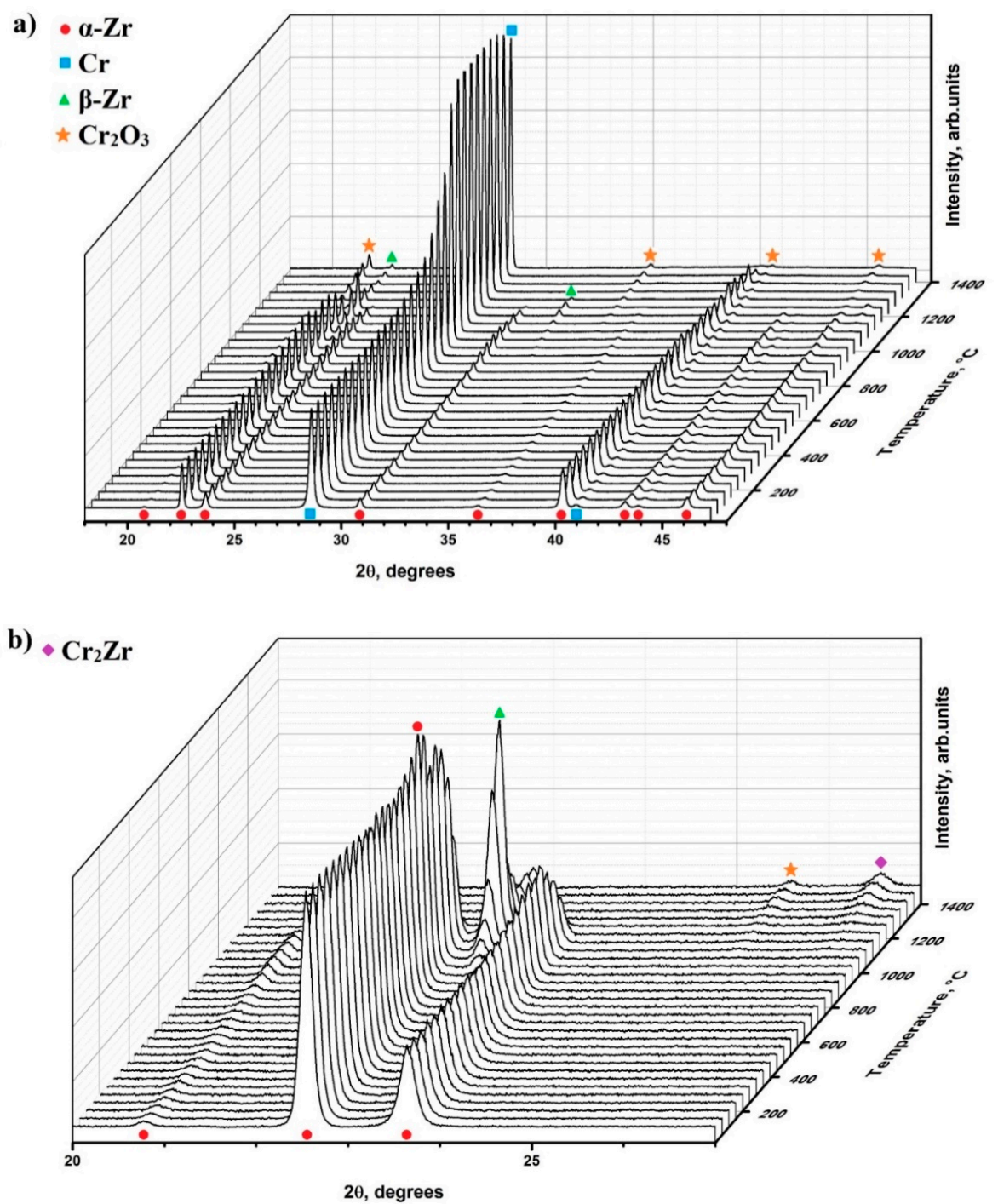

Figure 9. Phase transitions in E110 alloy with the $\mathrm{Cr}$ coating under linear heating in the temperature range of $25-1400{ }^{\circ} \mathrm{C}$ : (a) $2 \theta$ range of $19^{\circ}-47^{\circ}$; (b) zoom area of $20^{\circ}-27^{\circ}$. 
a)
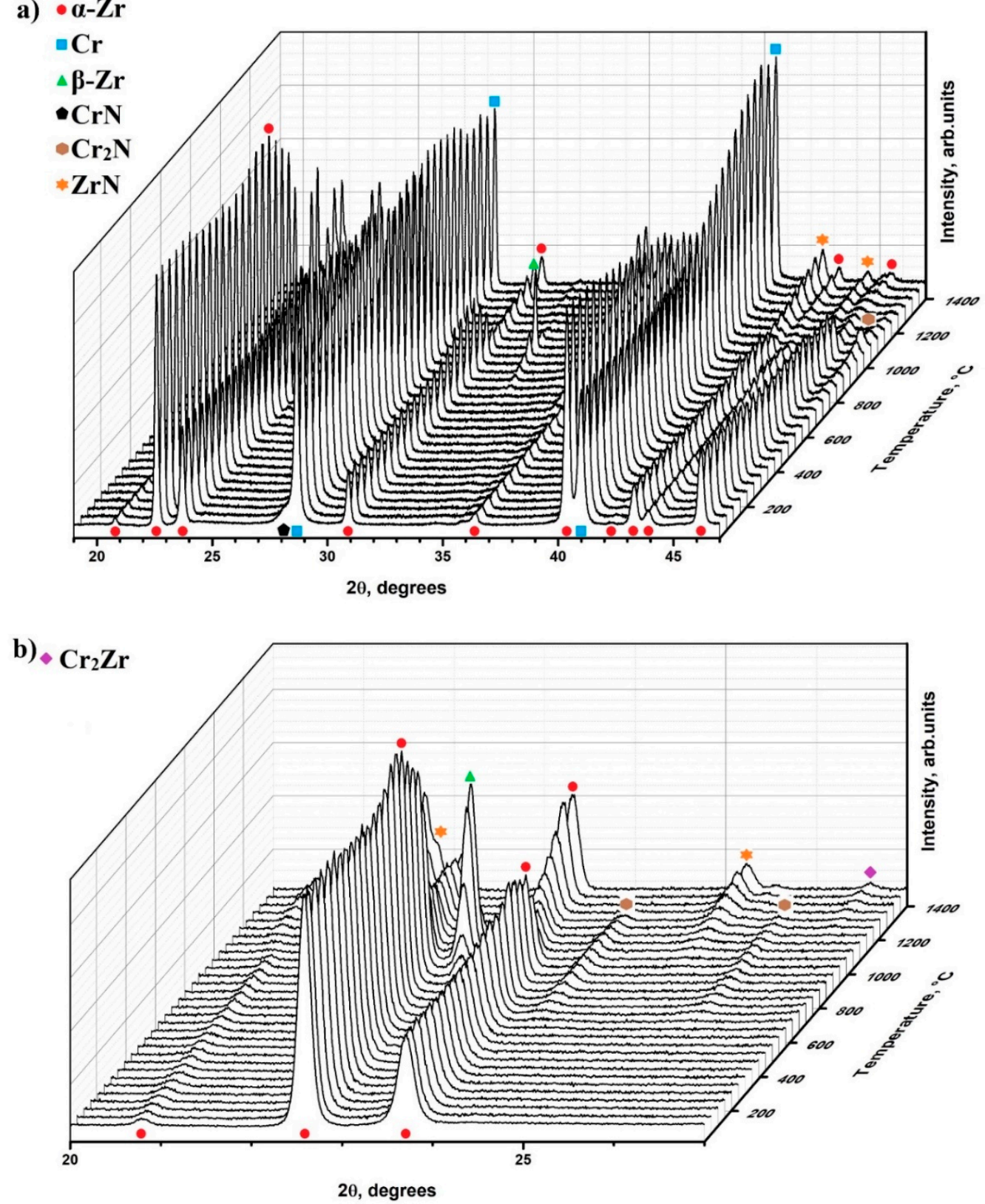

Figure 10. Phase transitions in E110 alloy with the $\mathrm{CrN} / \mathrm{Cr}-250$ coating under linear heating in the temperature range of $25-1400{ }^{\circ} \mathrm{C}$ : (a) $2 \theta$ range of $19^{\circ}-47^{\circ}$; (b) zoom area of $20^{\circ}-27^{\circ}$.

No phase changes occur in the sample with the multilayer $\mathrm{CrN} / \mathrm{Cr}-250$ coating only up to $600{ }^{\circ} \mathrm{C}$ (Figure 10a). The growth of $\mathrm{Cr}_{2} \mathrm{~N}$ phase begins at $650{ }^{\circ} \mathrm{C}$, while the intensity of $\mathrm{CrN}$ phase decreases. The temperature rise up to $900{ }^{\circ} \mathrm{C}$ is accompanied by $\alpha \rightarrow \beta$ phase transition of Zr. There is no complete $\alpha \rightarrow \beta$ transformation with increasing temperature, which is due to the partial decomposition of $\mathrm{CrN}$ to $\mathrm{Cr}_{2} \mathrm{~N}$ and the stabilization of the $\alpha-\mathrm{Zr}$ phase by nitrogen $\left(\alpha-\mathrm{Zr}(\mathrm{N})\right.$ phase). The simultaneous decrease in the reflections of $\mathrm{Cr}_{2} \mathrm{~N}$ phase and the appearance of the reflections of the $\mathrm{ZrN}$ phase are observed at $1000{ }^{\circ} \mathrm{C}$. This fact indicates the formation of the $\mathrm{ZrN}$ phase caused by the reaction of zirconium with nitrogen formed during the decomposition of the $\mathrm{Cr}_{2} \mathrm{~N}$ phase. The complete decomposition of the $\mathrm{Cr}_{2} \mathrm{~N}$ phase occurs at $1200-1250{ }^{\circ} \mathrm{C}$. It should be noted that the intermetallic $\mathrm{Cr}_{2} \mathrm{Zr}$ phase was observed only at the temperatures above $1350{ }^{\circ} \mathrm{C}$ (Figure 10b). 


\section{Discussion}

The oxidation behavior of E110 alloy with the metallic Cr coating is well correlated with recently published data [1,9]. As oxidation time increases, the fast $\mathrm{Cr}-\mathrm{Zr}$ interdiffusion and penetration of $\mathrm{O}$ and $\mathrm{N}$ to the $\mathrm{Zr}$ alloy results in the transition to nonprotective scale. In this case, oxidation kinetics of the coated alloy strongly accelerates (Figure 3). The analysis of the oxidized samples using OM, GDOES and XRD studies clearly shows such behavior (Figures 5-7 and 9).

The multilayer $\mathrm{CrN} / \mathrm{Cr}$ coatings can protect E110 alloy from oxidation for a longer time, which was evident by gravimetry tests (Figure 3). The difference between the weight gains of the samples coated with single layer $\mathrm{Cr}$ and multilayer $\mathrm{CrN} / \mathrm{Cr}$ coatings became greater as the oxidation time increased up to $30-40 \mathrm{~min}$. Taking into account the same thickness of the as-deposited coatings $(\sim 2.5 \mu \mathrm{m})$, two possible mechanisms can cause different oxidation kinetics of E110 alloy with $\mathrm{CrN} / \mathrm{Cr}$ coatings in comparison to the $\mathrm{Cr}$ coating. Firstly, the deposition of $\mathrm{CrN}$ instead of metallic chromium should enhance the oxidation resistance of coated alloy. Several comparative studies of oxidation behavior of $\mathrm{CrN}$ and $\mathrm{Cr}$ present questionable results due to the crucial role of $\mathrm{CrN}$ cracking in oxidation tests $[12,14,22]$. Thus, the oxidation kinetics of chromium nitride excluding cracking are still unclear. However, the $\mathrm{Cr}-\mathrm{Zr}$ inter-diffusion at the coating/alloy interface should have a higher impact, considering the low thickness of the as-deposited coatings. According to the last data of $\mathrm{Cr}-\mathrm{Zr}$ interaction at high temperatures [10], the thickness of the $\mathrm{Cr}-\mathrm{Zr}$ interlayer can be equal to $0.5-0.9 \mu \mathrm{m}$ at $1100{ }^{\circ} \mathrm{C}$ for $10-40 \mathrm{~min}$. This $\mathrm{Cr}$ consumption results in a decrease in diffusion path for oxygen and nitrogen to the $\mathrm{Zr}$ alloy. Based on OM and XRD data, the residual $\mathrm{Cr}$ layer was observed even after 40 min oxidation, while for the samples with the metallic $\mathrm{Cr}$ coating there was no $\alpha$-Cr phase. Calculations of phase composition show more than $50 \mathrm{wt} . \%$ content of $\alpha$-Cr in the multilayer $\mathrm{CrN} / \mathrm{Cr}-250$ coating.

The partial decomposition of $\mathrm{CrN}$ to $\mathrm{Cr}_{2} \mathrm{~N}$ resulted in inward nitrogen diffusion to the alloy and formation of $\alpha-\operatorname{Zr}(\mathrm{N})$ phase at the coating/alloy interface (Figure 10). Further decomposition of the $\mathrm{Cr}_{2} \mathrm{~N}$ phase at $\sim 1000^{\circ} \mathrm{C}$ led to the formation of a $\mathrm{ZrN}$ layer beneath the metallic (reduced) Cr layer. As indicated by Krejcí et al. [12], a thin $\mathrm{ZrN}$ layer can prevent chromium diffusion into the Zr-alloy and consequent embrittlement. The comparative in situ XRD studies confirm this statement. The shift of the $\mathrm{Cr}_{2} \mathrm{Zr}$ phase formation to higher temperatures (by $150{ }^{\circ} \mathrm{C}$ ) for the multilayer $\mathrm{CrN} / \mathrm{Cr}-250$ coating is shown.

It is known that brittle $\mathrm{CrN}$ films can crack under high temperature oxidation or mechanical deformations [12,22]. No cracking was observed for the multilayer $\mathrm{CrN} / \mathrm{Cr}$-250 and $\mathrm{CrN} / \mathrm{Cr}-500$ coatings (Figure 4 ) in the present study. Uniform oxide layers without local areas of accelerated oxidation were shown in the cross-section microstructures. At the same time, the sample with metallic $\mathrm{Cr}$ coating had a lot of cracks at the coating/alloy interface which caused accelerated oxidation in these regions. This is typical behavior for $\mathrm{Zr}$ alloys in a nitrogen rich atmosphere [26,27]. These results indicate both effects: deceleration of $\mathrm{Cr}-\mathrm{Zr}$ inter-diffusion kinetics and decreased nitrogen effect in the $\mathrm{Zr}$ alloy. This suggests a promising oxidation behavior of multilayer $\mathrm{CrN} / \mathrm{Cr}$ coatings at high temperatures.

In the present work, the coating thickness was chosen for detailed X-ray diffraction studies of diffusion mechanisms and phase transformations in multilayer $\mathrm{CrN} / \mathrm{Cr}$ coatings at high temperatures. Despite the good diffusion barrier properties of $\mathrm{CrN} / \mathrm{Cr}$ multilayers, the total thickness of the coatings (or the top $\mathrm{Cr}$ layer) should be higher to increase diffusion path of $\mathrm{O}$ and $\mathrm{N}$ to the alloy and to provide a protective scale for a longer period. Therefore, the oxidation kinetics of the E110 alloy with thicker $(10 \mu \mathrm{m}$ or more) $\mathrm{CrN} / \mathrm{Cr}$ coatings should be considered in future studies.

Another important point is related to the multilayer step (i.e., the thickness of $\mathrm{CrN}$ and Cr layers), which can influence the oxidation behavior of coated $\mathrm{Zr}$ alloys. This is clearly observed from the weight-gain measurements (Figure 3) and photographs of the samples (Table 2). For example, coating spallation/defects were found for the sample with the CrN/Cr-50 coating after 30-40 min oxidation, while other samples preserved their integrity. The coating with a multilayer step of $250 \mathrm{~nm}$ demonstrates better oxidation performance 
and cracking resistance compared to the $\mathrm{CrN} / \mathrm{Cr}$ coatings with 50 and $500 \mathrm{~nm}$ steps. This aspect should be also taken into account in future studies.

\section{Conclusions}

The oxidation behavior of E110 alloy with multilayer $\mathrm{CrN} / \mathrm{Cr}$ coatings was investigated in comparison to single layer metallic chromium. The multilayer step of $\mathrm{CrN}$ and Cr layers was 50, 250, or $500 \mathrm{~nm}$, while the total thickness of the coatings was $2.5 \mu \mathrm{m}$. The comparative analysis of their cross-section microstructures, elemental distributions over a depth, phase compositions after oxidation in air, and in situ XRD studies under high-temperature heating revealed the following conclusions:

1. The multilayer $\mathrm{CrN} / \mathrm{Cr}$ coatings have better protective properties in comparison to metallic $\mathrm{Cr}$ at $1100{ }^{\circ} \mathrm{C}$ in air. The results show higher weight gain for $\mathrm{Cr}$-coated E110 alloy $\left(\sim 20 \mathrm{mg} / \mathrm{cm}^{2}\right)$ compared to alloy with multilayer coatings $\left(\sim 9-13 \mathrm{mg} / \mathrm{cm}^{2}\right)$. The highest oxidation resistance belongs to the sample with the $\mathrm{CrN} / \mathrm{Cr}-250$ coating.

2. $\mathrm{CrN} / \mathrm{Cr}$ multilayers demonstrate barrier properties against $\mathrm{Cr}-\mathrm{Zr}$ inter-diffusion. The formation of a $\mathrm{ZrN}$ layer beneath the multilayer coating due to decomposition of chromium nitrides can decelerate the kinetics of $\mathrm{Cr}-\mathrm{Zr}$ inter-diffusion. For the considered total thickness $(\sim 2.5 \mu \mathrm{m})$ and multilayer step of $0.25 \mu \mathrm{m}$, the formation of the $\mathrm{Cr}_{2} \mathrm{Zr}$ phase occurs by $\sim 150{ }^{\circ} \mathrm{C}$ higher in comparison to metallic $\mathrm{Cr}$ coating.

3. No coating cracking or local accelerated oxidation are observed for the multilayer coatings with a layer step of 0.25 and $0.5 \mu \mathrm{m}$ after oxidation in air. Deposition of $\mathrm{CrN} / \mathrm{Cr}$ multilayers can decrease nitrogen effect during $\mathrm{Zr}$ oxidation.

Author Contributions: Conceptualization, D.V.S.; methodology, D.V.S. and M.S.S.; formal analysis, D.V.S. and M.S.S.; investigation, S.E.R. and A.V.P.; resources, M.S.S. and E.B.K.; data curation, S.E.R. and A.V.P.; writing original draft preparation, D.V.S.; writing — review and editing, M.S.S. and E.B.K.; visualization, S.E.R. and A.V.P.; supervision, D.V.S. and M.S.S.; project administration, D.V.S.; funding acquisition, D.V.S. All authors have read and agreed to the published version of the manuscript.

Funding: The reported study was funded by RFBR and ROSATOM, project number 20-21-00037.

Institutional Review Board Statement: Not applicable for studies not involving humans or animals.

Informed Consent Statement: Not applicable for studies not involving humans.

Data Availability Statement: Data are contained within the article.

Acknowledgments: The authors are grateful to Tomsk Polytechnic University Enhancement Program.

Conflicts of Interest: The authors declare no conflict of interest.

\section{References}

1. Brachet, J.C.; Rouesne, E.; Ribis, J.T.; Guilbert, S.; Urvoy, G. High temperature steam oxidation of chromium-coated zirconiumbased alloys: Kinetics and process. Corros. Sci. 2020, 167, 108537. [CrossRef]

2. Chen, H.; Wang, X.; Zhang, R. Application and development progress of Cr-based surface coatings in nuclear fuel element: I. selection, preparation, and characteristics of coating materials. Coatings 2020, 10, 808. [CrossRef]

3. Chen, H.; Wang, X.; Zhang, R. Application and development progress of Cr-based surface coating in nuclear fuel elements: II. Current status and shortcomings of performance studies. Coatings 2020, 10, 835. [CrossRef]

4. Sevecek, M.; Gurgen, A.; Seshadri, A.; Che, Y.; Wagih, M.; Phillips, B.; Champagne, V.; Shirvan, K. Development of Cr cold spray-coated fuel cladding with enhanced accident tolerance. Nucl. Eng. Technol. 2018, 50, 229-236. [CrossRef]

5. Yeom, H.; Maier, B.; Johnson, G.; Dabney, T.; Lenling, M.; Sridharan, K. High temperature oxidation and microstructural evolution of cold spray chromium coatings on Zircaloy-4 in steam environments. J. Nucl. Mater. 2019, 526, 151737. [CrossRef]

6. Kashkarov, E.B.; Sidelev, D.V.; Rombaeva, M.; Syrtanov, M.S.; Bleykher, G.A. Chromium coatings deposited by cooled and hot target magnetron sputtering for accident tolerant nuclear fuel claddings. Surf. Coat. Technol. 2020, 389, 125618. [CrossRef]

7. Kashkarov, E.B.; Sidelev, D.V.; Syrtanov, M.S.; Tang, C.; Steinbrück, M. Oxidation kinetics of Cr-coated zirconium alloy: Effect of coating thickness and microstructure. Corros. Sci. 2020, 175, 108883. [CrossRef] 
8. Wang, Y.; Zhou, W.; Wen, Q.; Ruan, X.; Luo, F.; Bai, G.; Qing, Y.; Zhu, D.; Huang, Z.; Zhang, Y.; et al. Behavior of plasma sprayed $\mathrm{Cr}$ coatings and $\mathrm{FeCrAl}$ coatings on $\mathrm{Zr}$ fuel cladding under loss-of-coolant accident conditions. Surf. Coat. Technol. 2018, 344, 141-148. [CrossRef]

9. Brachet, J.C.; Idarraga-Trujillo, I.; Le Flem, M.; Le Saux, M.; Vandenberghe, V. Early studies on Cr-coated zircaloy-4 as enhanced accident tolerant nuclear fuel claddings for light water reactors. J. Nucl. Mater. 2019, 517, 268-285. [CrossRef]

10. Yang, J.; Stegmaier, U.; Tang, C.; Steinbruck, M.; Große, M.; Wang, S.; Seifert, H. High temperature Cr-Zr interaction of two types of Cr-coated $\mathrm{Zr}$ alloys in inert gas environment. J. Nucl. Mater. 2021, 547, 152806. [CrossRef]

11. Tang, C.; Stueber, M.; Seifert, H.J.; Steinbrueck, M. Protective coatings on zirconium-based alloys as accident-tolerant fuel (ATF) claddings. Corros. Rev. 2017, 35, 141-165. [CrossRef]

12. Krejcí, J.; Kabátová, J.; Manoch, F.; Kočí, J.; Cvrček, L.; Málek, J. Development and testing of multicomponent fuel cladding with enhanced accidental performance. Nucl. Eng. Technol. 2020, 52, 597-609. [CrossRef]

13. Kuprin, A.S.; Belous, V.A.; Voyevodin, V.N.; Bryk, V.V.; Vasilenko, R.L.; Ovcharenko, V.D.; Reshetnyak, E.N.; Tolmachova, G.N.; V'yugov, P.N. Vacuum-arc chromium-based coatings for protection of zirconium alloys from the high-temperature oxidation in air. J. Nucl. Mater. 2015, 465, 400-406. [CrossRef]

14. Meng, C.; Yang, L.; Wu, Y.; Tan, J.; Dang, W.; He, X.; Ma, X. Study of the oxidation behavior of CrN coating on Zr alloy in air. J. Nucl. Mater. 2019, 515, 354-369. [CrossRef]

15. Tang, C.; Stüber, M.; Hans, J.; Steinbrück, M. Metallic and Ceramic Coatings for Enhanced Accident Tolerant Fuel Cladding. In Comprehensive Nuclear Materials, 2nd ed.; Konings, R.J.M., Stoller, R.E., Eds.; Elsevier: Amsterdam, The Netherlands, 2020; Volume 4, pp. 490-514. [CrossRef]

16. Musil, J.; Sklenka, J.; Procházka, J. Protective over-layer coating preventing cracking of thin films deposited on flexible substrates. Surf. Coat. Technol. 2013, 240, 275-280. [CrossRef]

17. Musil, J.; Sklenka, J.; Čerstvý, R. Protection of brittle film against cracking. Appl. Surf. Sci. 2016, 370, 306-311. [CrossRef]

18. Daub, K.; Van Nieuwenhove, R.; Nordin, V. Investigation of the impact of coatings on corrosion and hydrogen uptake of Zircaloy-4. J. Nucl. Mater. 2015, 467, 260-270. [CrossRef]

19. Tallman, D.; Anasori, B.; Barsoum, M.A. Critical review of the oxidation of $\mathrm{Ti}_{2} \mathrm{AlC}, \mathrm{Ti}_{3} \mathrm{AlC}_{2}$ and $\mathrm{Cr}_{2} \mathrm{AlC}$ in air. Mater. Res. Lett. 2013, 1, 115-125. [CrossRef]

20. Skarohlid, J.; Skoda, R. High temperature behaviour of CrAlSiN MAX phase coatings on zirconium alloy. In Proceedings of the 2017 Water Reactor Fuel Performance 2017, Jeju, Korea, 10-14 September 2017.

21. Ma, X.; Wu, Y.; Tan, J.; Meng, C.; Yang, L.; Dang, W.; He, X. Evaluation of corrosion and oxidation behaviors of TiAlCrN coatings for nuclear fuel cladding. Surf. Coat. Technol. 2019, 358, 521-530. [CrossRef]

22. Krejci, J.; Sevecek, M.; Cvrcek, L. Development of chromium and chromium nitride coated cladding for VVER reactors. In Proceedings of the 2017 Water Reactor Fuel Performance, Jeju, Korea, 10-14 September 2017.

23. Sidelev, D.V.; Kashkarov, E.B.; Syrtanov, M.S.; Krivobokov, V.P. Nickel-chromium (Ni-Cr) coatings deposited by magnetron sputtering for accident tolerant nuclear fuel claddings. Surf. Coat. Technol. 2019, 369, 69-78. [CrossRef]

24. Zhou, X.; Liu, D.; Bu, H.; Deng, L.; Liu, H.; Yuan, P.; Du, P.; Song, H. XRD-based quantitative analysis of clay minerals using reference intensity ratios, mineral intensity factors, Rietveld, and full pattern summation methods: A critical review. Solid Earth Sci. 2018, 3, 16-29. [CrossRef]

25. Perez, R.A.; Nakajima, H.; Dyment, F. Diffusion in -Ti and Zr. Mater. Trans. 2003, 44, 2-13. [CrossRef]

26. Steinbrueck, M.; Silva, F.O.; Grosse, M. Oxidation of Zircaloy-4 in steam-nitrogen mixtures at $600-1200{ }^{\circ}$ C. J. Nucl. Mater. 2017, 490, 226-237. [CrossRef]

27. Duriez, C.; Dupont, T.; Schmet, B.; Enoch, F. Zircaloy-4 and M5 high temperature oxidation and nitriding in air. J. Nucl. Mater. 2008, 380, 30-45. [CrossRef] 